\title{
Sistem Penunjang Keputusan Strategi Tindakan Atas Pelanggaran Siswa Dengan Metode Analytical Network Process
}

\author{
Fajar Delli Wihartiko, Eneng Tita Tosida, Lola Jaman Sentosa \\ Program Studi IImu Komputer Universitas Pakuan \\ E-mail: fajardelli@unpak.ac.id
}

\begin{abstract}
Dalam proses belajar mengajar, siswa dapat saja melakukan pelanggaran baik dalam kategori ringan maupun berat. Setiap pelanggaran memiliki tindakan atau hukuman sesuai dengan aturan yang berlaku. Guna mempermudah proses pengambilan keputusan atas tindakan yang terjadi perlu dibuat suatu sistem penunjang keputusan atas pelanggaran yang terjadi. Sistem tersebut dibuat menggunakan metode Analytycal Network Process. Model yang dihasilkan kemudian dikembangkan dalam bentuk system penunjang keputusan berbasis web. Proses pengembangan system dilakukan pada Sekolah Menengah Kejuruan (SMK) Infokom Bogor. Sistem yang telah dikembangkan dapat digunakan sebagai bahan evaluasi pihak sekolah dalam mengupayakan kedisiplinan.
\end{abstract}

Keywords: Sistem Penunjang Keputusan, Analytycal Network Process, Kedisiplinan

\section{Abstract}

In teaching and learning process, students can only commit violations in both light and severe categories. Every violation has an action or punishment in accordance with the applicable rules. In order to facilitate the process of making decisions on the actions that occur, a decision support system must be made for violations that occur. The system was created using the Analytycal Network Process method. The resulting model is then developed in the form of a web-based decision support system. The system development process is carried out at the Infokom Vocational High School (SMK) Bogor. The system that has been developed can be used as an evaluation material for the school in seeking discipline.

Keywords: Decision Support Systems, Analytycal Network Process, Discipline

\section{Pendahuluan}

Disiplin merupakan aspek utama membentuk peserta didik pada dunia pendidikan dalam upaya mengembangkan pemahaman diri sesuai dengan kecakapan, minat, pribadi dan hasil belajar, mewujudkan peserta didik berperilaku baik dan berprestasi. Namun, ketidakdisiplinan masih seringkali terjadi dan menjadi hambatan dalam mencapai kesesuaian perilaku yang diharapkan dan terciptanya kenyamanan kegiatan pembelajaran. Hal ini diantisipasi dan diatasi dengan berbagai cara diantaranya adalah memberikan sanksi kepada peserta didik yang berperilaku tidak disiplin. Sanksi yang diberikan harus memiliki strategi dan memenuhi beberapa aspek, diantaranya adalah dapat membantu membiasakan anak mengendalikan dan mengekang perilaku yang diinginkan serta memiliki nilai pendidikan.

Salah satu upaya pendisiplinan diri pada SMK Infokom Bogor adalah diterapkannya sistem poin bagi peserta didik yang melanggar aturan sekolah. Sistem poin akan diberikan kepada peserta didik yang diketahui melanggar aturan sekolah kemudian poin akan diakumulasi selama tiga bulan sekali dan dilakukan evaluasi. Sistem tersebut memiliki beberapa kelemahan, diantaranya adalah seringkali terdapat beberapa pelanggaran yang tidak terdaftar dalam aturan sehingga guru bimbingan konseling kurang objektif dalam pemberian sanksi. Selain itu, sanksi yang diberikan sesuai poin yang diperoleh terkadang tidak memberikan efek jera dan tidak membuat peserta didik berperilaku sesuai aturan. Oleh karena itu, perlu adanya 
suatu sistem yang memiliki strategi yang dapat memberikan solusi langkah awal dalam menangani ketidakdisiplinan peserta didik tersebut.

Terdapat beberapa penelitian tentang sistem penunjang keputusan mengenai pelanggaran siswa yang telah dilakukan oleh beberapa peniliti, diantaranya Triliyana [1] menggunakan metode Forward Chaining/pelacakan kedepan, yang memulai pencarian dari data/kondisi yang ada menuju pada kesimpulan. Handayani [2] telah membuat aplikasi untuk mengetahui tingkat kedisiplinan dan sanksi pelanggaran yang dilakukan siswa Sekolah Menengah Atas Negeri (SMAN) 1 Jatinom menggunakan sistem pendukung keputusan dengan metode Technique Order Preference by Similarity To Ideal Solution (TOPSIS). Krisnuari [3] merancang aplikasi sistem pendukung keputusan untuk membantu dalam menentukan jenis sanksi pelanggaran terhadap siswa yang melakukan pelanggaran agar tidak terjadi kesalahan dalam memberikan sanksi pelanggaran.

Berdasarkan hal tersebut perumusan strategi penanganan siswa sangat diperlukan oleh pihak Sekolah. Perumusan strategi tindakan atas pelanggaran siswa ini akan memudahkan praktisi sekolah dengan adanya metode pemeringkatan tindakan penanganan siswa, metode pemeringkatan ini dapat diterapkan menggunakan konsep Analytical Network Process (ANP). $\mathrm{Hal}$ ini yang mendasari perancangan Sistem Penunjang Keputusan Strategi Tindakan Atas Pelanggaran Siswa Dengan Metode Analytical Network Process. Metode ANP pada sistem ini akan memanfaatkan aplikasi Super Decision sebagai pemroses data, dengan MySQL sebagai basis data dan bahasa pemrograman PHP sebagai penampil hasil pemeringkatan dengan harapan sistem penunjang keputusan ini dapat dimanfaatkan oleh praktisi sekolah dalam mengoptimalisasi penanganan pelanggaran upaya pendisiplinan siswa. Dalam tulisan ini akan dirancang suatu sistem untuk menentukan perumusan strategi tindakan atas pelanggaran siswa dengan menerapkan suatu metode pemeringkatan sanksi. Turban dan Aronson [4] mendefiniskan sistem penunjang keputusan (Decision Support Systems - DSS) sebagai sistem yang digunakan untuk mendukung dan membantu pihak manajemen melakukan pengambilan keputusan pada kondisi semi terstruktur dan tidak terstruktur.

\section{Metode Penelitian}

Tahapan dalam mengimplementasikan sistem pendukung keputusan dalam penelitian ini menggunakan model Sistem Development Life Cycle (SDLC) yang merupakan sebuah pendekatan kepada perkembangan perangkat lunak yang sistematik dan sekuensial yang mulai pada tingkat dan kemajuan sistem pada seluruh tahapannya, tahapan tersebut dimulai dari tahap perencanaan, analisis, perancangan, implementasi, uji coba, dan terakhir tahap penggunaan sistem. Berikut adalah model SDLC yang ditunjukkan pada Gambar 1.

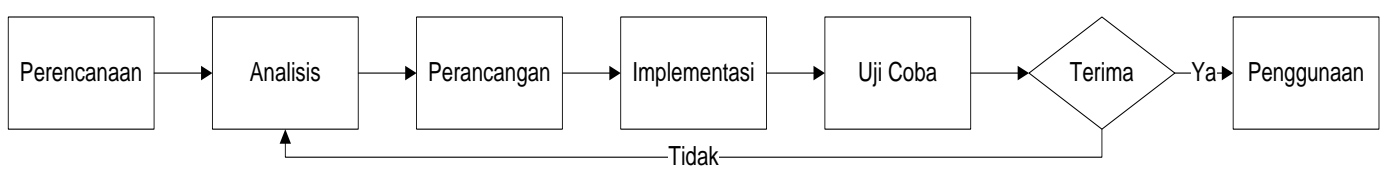

Gambar 7 Gambar Tahapan SDLC [5]

\subsection{Perencanaan}

Perencanaan merupakan sebuah proses dasar untuk memahami mengapa sebuah sistem harus dibangun. Pada tahap ini diperlukan adanya analisis kelayakan dengan mencari data atau melakukan proses pengumpulan segala informasi kepada pengguna melalui wawancara ataupun kuesioner. Sehingga dalam tahap ini dihasilkan suatu kebutuhan pengguna dalam melakukan pendataan sanksi dari pelanggaran siswa agar lebih objektif. Wawancara dilakukan dengan praktisi SMK Infokom Bogor, diantaranya adalah Wakil Kepala Sekolah Bagian Kesiswaan, Koordinator Bimbingan konseling dan Pembina Organiosasi Siswa Intra Sekolah (OSIS). Ketiganya merupakan praktisi sekolah yang berhubungan langsung dengan upaya kedisiplinan siswa baik dalam pelaksanaan, controlling maupun evaluasi dan pemangku keputusan. Pada tahap ini pula dirumuskan permasalahan yang ada pada SMK Infokom Bogor yaitu cara meningkatkan kedisiplinan siswa dengan menerapkan strategi tindakan penanganan siswa yang sesuai dengan kondisi lingkungan pendidikan yang ada pada sekolah tersebut. 


\subsection{Analisis}

Pada tahap analisis dilakukan pengidentifikasian terhadap kebutuhan sistem, hal ini dilakukan sebagai acuan dalam pembuatan sistem penunjang keputusan strategi tindakan atas pelanggaran siswa di SMK Infokom Bogor. Perancangan sistem yang akan dibangun menggunakan metode Analytical Network Process perlu ditentukan kelompok (cluster) kriteria, subkriteria maupun alternatif yang merupakan bagian yang dibutuhkan dari sistem penunjang keputusan strategi tindakan atas pelanggaran siswa sebagai penentu proses perhitungan dalam pembuatan sistem.Kelompok (cluster) dibuat berdasarkan kelompok kriteria yaitu pelanggaran yang sering kali terjadi, dan kelompok alternatif yaitu sanksi yang telah ditetapkan dan diberlakukan pada aturan SMK Infokom Bogor. Kelompok kriteria diantaranya yaitu pelanggaran seragam dan atribut, pelanggaran rambut, kuku, tato make up dan pelanggaran disiplin siswa. Setiap kriteria memiliki subkriteria masing-masing sesuai dengan jenis pelanggarannya yang disajikan pada Tabel 1. Kelompok alternatif terdiri dari tujuh sanksi yang diterapkan bagi siswa yang melanggar, yaitu peringatan lisan dan istigfar, peringatan tertulis dan hukuman edukatif, panggilan orang tua/wali murid, dikembalikan kepada orang tua dalam jangka waktu tertentu (skors) 3 hari, dikembalikan kepada orang tua dalam jangka waktu tertentu (skors) 7 hari/1 minggu, dikembalikan kepada orang tua selamanya/masa kritis di sekolah, dikembalikan kepada orang tua selamanya, dapat dilihat pada Tabel 2. Gambar 1 menunjukan model ANP yang menghubungkan kriteria jenis pelanggaran dan daftar alternatif.

\begin{tabular}{|c|c|c|c|}
\hline \multicolumn{2}{|c|}{ KRITERIA } & \multicolumn{2}{|r|}{ SUB KRITERIA } \\
\hline \multirow[t]{4}{*}{$\mathrm{K} 1$} & \multirow{4}{*}{$\begin{array}{l}\text { Pelanggaran } \\
\text { Seragam } \\
\text { dan Atribut }\end{array}$} & SK1 & Baju tidak dimasukkan \\
\hline & & SK2 & $\begin{array}{l}\text { Seragam tidak sesuai dengan ketentuan dan atau } \\
\text { atribut tidak lengkap }\end{array}$ \\
\hline & & SK3 & Tidak memakai sepatu sesuai dengan ketentuan \\
\hline & & SK4 & $\begin{array}{l}\text { Mengubah, menambah, mengurangi tulisan atau } \\
\text { gambar pada pakaian seragam atau atribut sekolah }\end{array}$ \\
\hline \multirow[t]{5}{*}{ K2 } & \multirow{5}{*}{$\begin{array}{l}\text { Pelanggaran } \\
\text { rambut, } \\
\text { kuku, tato } \\
\text { dan make up }\end{array}$} & SK5 & Memakai pewarna kuku \\
\hline & & SK6 & $\begin{array}{l}\text { Berambut gondrong/panjang tidak sesuai dengan } \\
\text { ketentuan (bagi murid putra) }\end{array}$ \\
\hline & & SK7 & Memakai pewarna rambut \\
\hline & & SK8 & $\begin{array}{l}\text { Murid putra memakai giwang, kalung, cincin atau } \\
\text { perhiasan lain yang lazim dipakai wanita }\end{array}$ \\
\hline & & SK9 & $\begin{array}{l}\text { Bersolek dan mengenakan perhiasan secara } \\
\text { berlebihan }\end{array}$ \\
\hline \multirow[t]{3}{*}{ K3 } & \multirow{3}{*}{$\begin{array}{l}\text { Pelanggaran } \\
\text { disiplin siswa }\end{array}$} & SK10 & Datang terlambat kurang dari 15 menit \\
\hline & & SK11 & $\begin{array}{l}\text { Datang terlambat lebih dari } 15 \text { menit tetapi kurang dari } \\
30 \text { menit }\end{array}$ \\
\hline & & SK12 & $\begin{array}{l}\text { Datang terlambat lebih dari } 30 \text { menit tanpa } \\
\text { keterangan }\end{array}$ \\
\hline
\end{tabular}

Tabel 2. Daftar Alternatif

\begin{tabular}{cl}
\hline Kode & Alternatif \\
\hline A1 & Peringatan lisan dan istigfar \\
A2 & Peringatan tertulis dan hukuman edukatif \\
A3 & Panggilan orang tua/wali murid \\
A4 & Dikembalikan kepada orang tua dalam jangka waktu tertentu (skors) 3 hari \\
A5 & Dikembalikan kepada orang tua dalam jangka waktu tertentu (skors) 7 hari/1 \\
A6 & Dingembalikan kepada orang tua selamanya/masa kritis di sekolah \\
A7 & Dikembalikan kepada orang tua selamanya \\
\hline
\end{tabular}

Komputasi Vol. 15, No. 1, January 2018: $89-139$ 


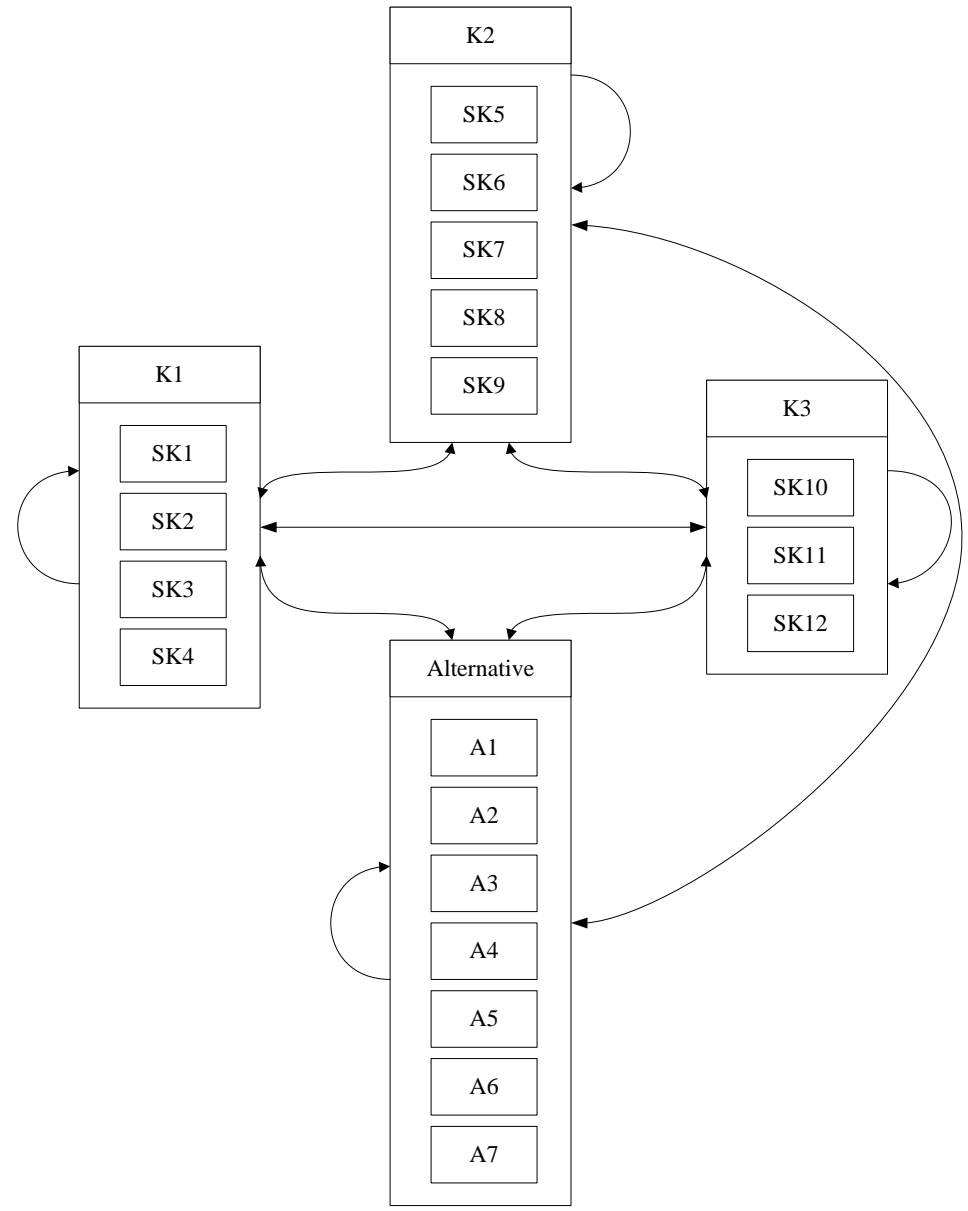

Gambar 1. Model ANP

\subsection{Perancangan}

Tahap perancangan merupakan sebuah proses penentuan cara kerja sistem dalam hal arsitektur desain, desain antarmuka, struktur database, serta desain program.:

1. Perancangan Basis Data, Perancangan basis data adalah perancangan yang dilakukan dengan membuat struktur-struktur tabel dari Entity Relationship Diagram (ERD) hasil tahap analisis yang akan menjadi bagian pembuatan database.

2. Perancangan Basis Model, Perancangan basis model merupakan perancangan yang dilakukan dengan pembuatan jaringan hiernet pada metode Analytical Netwok Process yang menghubungkan komponen kriteria, sub kriteria dan alternatif dari hasil tahap analisis yang akan menjadi bagian proses pengolahan sistem.

3. Perancangan Dialog, Perancangan dialog merupakan perancangan yang dilakukan dengan membuat flowchart sistem, struktur navigasi serta desain halaman sistem dari Data Flow Diagram (DFD) hasil tahap analisis yang akan menjadi bagian dari pembuatan antarmuka sistem.

\subsection{Implementasi, Uji Coba dan Penggunaan}

Implementasi sistem merupakan hasil dari desain sistem yang telah dirancang kemudian diimplementasikan pada sebuah program komputer. Tahap implementasi ini meliputi Implementasi Basis Data, Implementasi Basis Model dan Implementasi Dialog

Uji coba dilakukan setelah pembuatan sistem selesai dibuat, dengan tujuan mengetahui kekurangan sistem yang telah dibuat, pada tahap penelitian ini dilakukan melalui black box dan uji sensitivitas.. 
Pada tahap penggunaan dilakukan proses pengimp[lementasian sistem oleh pengguna dan pemeliharaan sistem yang berguna untuk menjaga keandalan sistem yang telah dibuat dan untuk memperbaharui keinginan pengguna/user, agar sistem dapat berinteraksi lebih baik lagi dengan pengguna/user. Pengembangan sistem kemungkinan dapat dikembangkan sesuai dengan kebutuhan.

\section{Hasil dan Pembahasan}

Hasil dari penelitian ini berupa pemeringkatan alternatif dengan metode Analytical Network Process sistem penunjang keputusan strategi tindakan atas pelanggaran siswa. Strategi yang didapatkan dari sistem ini berupa pemeringkatan sanksi yang sesuai dan dapat menjadi saran untuk bisa diterapkan pada SMK Infokom Bogor. Pemeringkatan alternatif sanksi ditunjukkan dalam sebuah grafik yang menghasilkan bahwa sanksi peringatan tertulis dan hukuman edukatif (A2) merupakan hasil yang mendapatkan nilai tertinggi. Hal tersebut sesuai dari ketiga pendapat pakar dalam penelitian ini yaitu Wakil Kepala Sekolah Bidang Kesiswaan, Koordinator Bimbingan Konseling dan Pembina OSIS.

Hasil ini menunjukkan bahwa tindakan yang paling sesuai dan paling cocok untuk diterapkan pada SMK Infokom Bogor dalam upaya meningkatkan kedisiplinan siswa adalah peringatan tertulis dan hukuman edukatif (A2). Setelah peringatan tertulis dan hukuman edukatif (A2) adalah peringkat kedua yaitu panggilan orang tua/wali murid (A3) yang cocok diterapkan apabila alternatif sebelumnya tidak menunjukkan adanya perubahan kedisiplinan siswa. Di peringkat ketiga selanjutnya yaitu peringatan lisan dan istigfar (A1), kemudian di peringkat keempat yaitu dikembalikan kepada orang tua dalam jangka waktu tertentu (skors) 3 hari (A4), di peringkat kelima yaitu dikembalikan kepada orang tua dalam jangka waktu tertentu (skors) 7 hari/1 minggu (A5), di peringkat ke enam dikembalikan kepada orang tua selamanya/masa kritis di sekolah (A6), dan di peringkat terakhir yaitu dikembalikan kepada orang tua selamanya/masa kritis di sekolah(A7). Grafik hasil pemeringkatan alternatif tindakan penanganan siswa disajikan oleh Gambar 2.

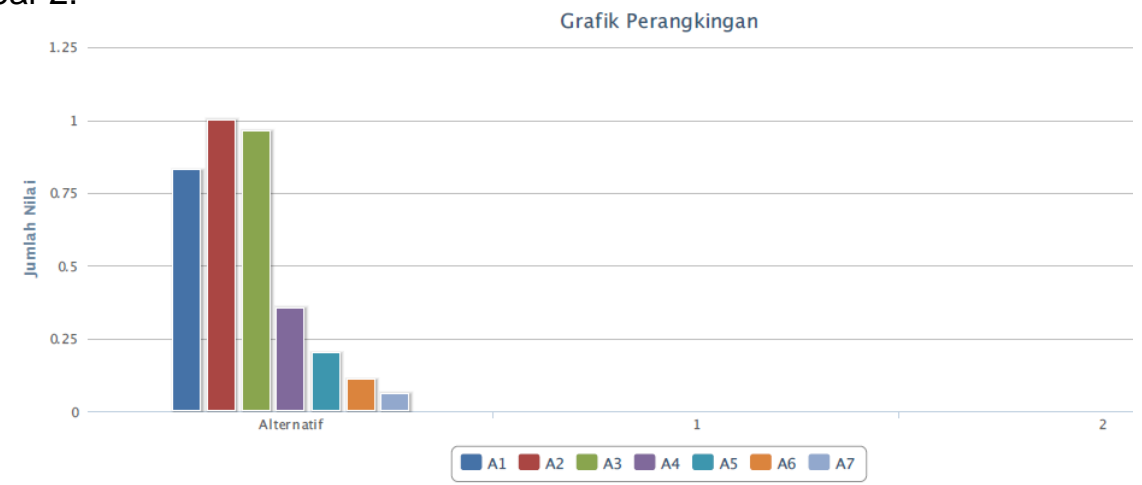

Gambar 2. HasilPemeringkatan Alternatif

Nilai hasil pemeringkatan alternatif dengan menggunakan metode Analytical Network Process dapat dilihat seperti pada Tabel 3.

Tabel 3. Hasil Pemeringkatan Alternatif

\begin{tabular}{cclc}
\hline Peringkat & Kode & \multicolumn{1}{c}{ Tindakan } & $\begin{array}{c}\text { Nilai } \\
\text { Normalisasi }\end{array}$ \\
\hline 1 & A2 & Peringatan tertulis dan hukuman edukatif & 0,28395 \\
2 & A3 & Panggilan orang tua / wali murid & 0,27336 \\
3 & A1 & $\begin{array}{l}\text { Peringatan lisan dan istigfar } \\
\text { Dikembalikan kepada orang tua dalam jangka } \\
\text { waktu tertentu (skorsing) 3 hari }\end{array}$ & 0,23553 \\
4 & A4 & 0,10094 \\
5 & A5 & $\begin{array}{l}\text { Dikembalikan kepada orang tua dalam jangka } \\
\text { waktu tertentu (skorsing) 7 hari / 1 minggu }\end{array}$ & 0,057 \\
6 & A6 & $\begin{array}{l}\text { Dikembalikan kepada orang tua selamanya / } \\
\text { masa kritis di sekolah }\end{array}$ & 0,0317 \\
7 & A7 & Dikembalikan kepada orang tua selamanya & 0,0175 \\
\hline
\end{tabular}

Komputasi Vol. 15, No. 1, January 2018 : $89-139$ 
Selain nilai pemeringkatan alternatif tindakan penanganan siswa, didapatkan pula nilai hasil pemeringkatan pelanggaran yang terjadi pada SMK Infokom Bogor. Nilai ini didapatkan dari hasil perbandingan berpasangan yang diperoleh dari ketiga orang pakar. Nilai pemeringkatan ini menunjukkan prioritas pelanggaran yang paling utama untuk diberikan penanganan/tindakan. Di urutan pertama adalah pelanggaran datang terlambat lebih dari 30 menit tanpa keterangan (SK12), menunjukkan bahwa pelanggaran SK12 ini adalah pelanggaran yang memiliki bobot paling besar untuk bisa diutamakan diberikan penanganan/tindakan. Di urutan kedua adalah pelanggaran seragam tidak sesuai dengan ketentuan dan atau atribut tidak lengkap (SK2) untuk bisa segera diberikan penanganan, di urutan ketiga pelanggaran berambut gondrong/panjang tidak sesuai dengan ketentuan (bagi murid putra) (SK6) untuk bisa segera diberikan penanganan/tindakan, selengkapnya dapat dilihat seperti pada Tabel 4.

Tabel 4. Hasil Pemeringkatan Pelanggaran

\begin{tabular}{cclc}
\hline Peringkat & Kode & \multicolumn{1}{c}{ Pelanggaran } & $\begin{array}{c}\text { Nilai } \\
\text { Normalisasi }\end{array}$ \\
\hline 1 & SK12 & $\begin{array}{l}\text { Datang terlambat lebih dari 30 menit tanpa } \\
\text { keterangan }\end{array}$ & 0,66805 \\
2 & SK2 & $\begin{array}{l}\text { Seragam tidak sesuai dengan ketentuan dan } \\
\text { atau atribut tidak lengkap }\end{array}$ & 0,53831 \\
3 & SK6 & $\begin{array}{l}\text { Berambut gondrong/panjang tidak sesuai } \\
\text { dengan ketentuan (bagi murid putra) }\end{array}$ & 0,30679 \\
4 & SK8 & $\begin{array}{l}\text { Murid putra memakai giwang, kalung, cincin } \\
\text { atau perhiasan lain yang lazim dipakai wanita }\end{array}$ & 0,30679 \\
5 & SK9 & $\begin{array}{l}\text { Bersolek dan mengenakan perhiasan secara } \\
\text { berlebihan }\end{array}$ & 0,30679 \\
6 & SK4 & $\begin{array}{l}\text { Mengubah, menambah, mengurangi tulisan } \\
\text { atau gambar pada pakaian seragam atau } \\
\text { atribut sekolah }\end{array}$ & 0,30321 \\
7 & SK11 & $\begin{array}{l}\text { Datang terlambat lebih dari 15 menit tetapi } \\
\text { kurang dari 30 menit }\end{array}$ & 0,26651 \\
8 & SK3 & $\begin{array}{l}\text { Tidak memakai sepatu sesuai dengan } \\
\text { ketentuan }\end{array}$ & 0,11168 \\
9 & SK10 & $\begin{array}{l}\text { Datang terlambat kurang dari 15 menit } \\
\text { Baju tidak dimasukkan }\end{array}$ & 0,06545 \\
10 & SK1 & $\begin{array}{l}\text { Memakai pewarna rambut } \\
\text { Memakai pewarna kuku }\end{array}$ & 0,046876 \\
12 & SK7 & SK5 & Memb87 \\
\hline
\end{tabular}

Sistem penunjang keputusan strategi tindakan atas pelanggaran siswa ini adalah implementasi dari bahasa pemrograman PHP, MySQL sebagai basis data dan aplikasi Super Decision sebagai pengolah data pakar. Metode yang diterapkan oleh aplikasi ini adalah metode Analytical Network Process (ANP). ANP adalah suatu metode pemecahan suatu masalah yang tidak terstruktur dan membutuhkan ketergantungan hubungan antar elemennya. ANP dikembangkan dari Analytical Hierarchy Process (AHP) atas dasar hubungan saling ketergantungan antar beberapa komponen.

Penelitian ini dilakukan dari proses wawancara kepada praktisi sekolah mengenai peraturan sekolah hingga kedisiplinan siswa. Menurut Suradinata [6], disiplin pada dasarnya mencakup pelajaran, patuh, taat, kesetiaan, hormat kepada ketentuan/peraturan/norma yang berlaku. Pada kenyataannya banyak hal yang memengaruhi perilaku siswa untuk menjaga kedisiplinan, mulai dari budaya, kemajuan teknologi, perlakuan di sekolah, hingga tidak objektifnya sanksi yang diterapkan. Hal ini yang menjadikan dasar sebagai bentuk perlu adanya sebuah sistem yang menghasilkan keputusan berupa alternatif tindakan/penanganan terbaik agar dapat mengevaluasi sikap ketidakdisiplinan tersebut. Alternatif tindakan terbaik yang akan dihasilkan pada sistem penunjang keputusan ini diterapkan dengan metode Analytical Network Process (ANP). 
ANP adalah teori umum pengukuran relatif yang digunakan untuk menurunkan rasio prioritas komposit dari skala rasio individu yang mencerminkan pengukuran relatif dari pengaruh elemen-elemen yang saling berinteraksi berkenaan dengan kriteria kontrol [7]. Metode ANP dihasilkan dari perhitungan perbandingan kelompok (cluster), kriteria dan sub kriteria, serta alternatif. Kelompok (cluster) pada sistem ini terdiri dari pelanggaran-pelanggaran yang sering terjadi serta alternatif tindakan/penanganan yang ada pada SMK Infokom Bogor. Kriteria yang digunakan dalam sistem ini adalah pelanggaran seragam dan atribut (K1), pelanggaran rambut, kuku, tato, make dan make up (K2), pelanggaran disiplin siswa (K3). Alternatif tindakan/penanganan yang digunakan dalam sistem ini adalah peringatan lisan dan istigfar (A1), peringatan tertulis dan hukuman edukatif (A2), panggilan orang tua/wali murid (A3), dikembalikan kepada orang tua dalam jangka waktu tertentu (skors) tiga hari (A4), dikembalikan kepada orang tua dalam jangka waktu tertentu (skors) tujuh hari/satu minggu (A5), dikembalikan kepada orang tua selamanya/masa kritis di sekolah (A6), dan dikembalikan kepada orang tua selamanya (7).

Tabel 5. Nilai Uji Sensitivitas

\begin{tabular}{cccccc}
\hline Kode & Nilai Bobot Awal & $\begin{array}{c}\text { Nilai Bobot Uji } \\
\text { Sensitivitas }\end{array}$ & Kode & $\begin{array}{c}\text { Nilai Bobot } \\
\text { Awal }\end{array}$ & $\begin{array}{c}\text { Nilai Bobot Uji } \\
\text { Sensitivitas }\end{array}$ \\
\hline A1 & 0,23553 & 0,642 & A4 & 0,10094 & 0,047 \\
A2 & 0,28395 & 0,133 & A5 & 0,057 & 0,027 \\
A3 & 0,27336 & 0,128 & A6 & 0,0317 & 0,015 \\
& & & A7 & 0,0175 & 0,008 \\
\hline
\end{tabular}

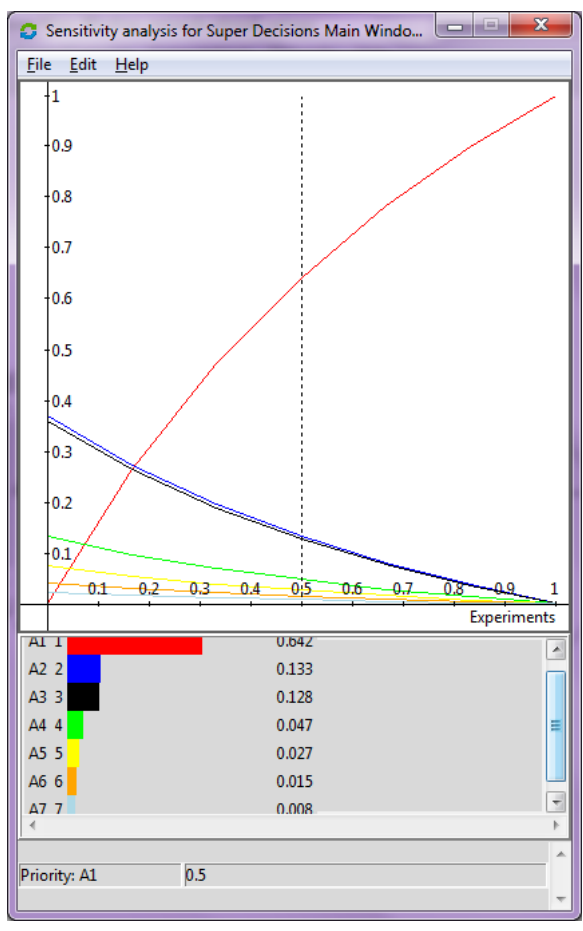

Gambar 3. Uji Sensitivitas
Tabel 6. Hasil pengujian Black Box

\begin{tabular}{|c|c|c|c|c|}
\hline Prosedur & Masukan & $\begin{array}{c}\begin{array}{c}\text { Keluaran } \\
\text { yang } \\
\text { Diharapkan }\end{array} \\
\end{array}$ & Kriteria Evaluasi Hasil & $\begin{array}{c}\text { Hasil yang } \\
\text { Didapat }\end{array}$ \\
\hline $\begin{array}{l}\text { Memasukkan } \\
\text { nama } \\
\text { username, } \\
\text { sandi }\end{array}$ & $\begin{array}{l}\text { Username, } \\
\text { sandi. } \\
\text { Tekan } \\
\text { tombol } \\
\text { Login }\end{array}$ & $\begin{array}{l}\text { Ada box } \\
\text { pesan untuk } \\
\text { keberhasilan } \\
\text { login }\end{array}$ & $\begin{array}{l}\text { Apabila ada text field } \\
\text { data yang tidak diisi } \\
\text { akan muncul pop-up } \\
\text { "username dan sandi } \\
\text { salah" }\end{array}$ & Sukses \\
\hline $\begin{array}{l}\text { Memilih } \\
\text { menu } \\
\text { "matrix" }\end{array}$ & $\begin{array}{l}\text { Menu } \\
\text { "matrix" }\end{array}$ & $\begin{array}{l}\text { Muncul } \\
\text { menu pilihan } \\
\text { matrix }\end{array}$ & $\begin{array}{l}\text { Terdapat empat } \\
\text { pilihan matrix, yaitu } \\
\text { unweighted } \\
\text { supermatrix, weighted } \\
\text { matrix, cluster matrix } \\
\text { dan limit matrix }\end{array}$ & Sukses \\
\hline $\begin{array}{l}\text { Memilih } \\
\text { menu } \\
\text { unweighted } \\
\text { supermatrix }\end{array}$ & Menu & $\begin{array}{l}\text { Muncul } \\
\text { tabel } \\
\text { matriks }\end{array}$ & $\begin{array}{l}\text { Terdapat tabel } \\
\text { matriks yang telah } \\
\text { disimpan }\end{array}$ & Sukses \\
\hline $\begin{array}{l}\text { pilih menu } \\
\text { "kuesioer", } \\
\text { tombol "isi } \\
\text { data" }\end{array}$ & $\begin{array}{l}\text { Masukkan } \\
\text { hasil input } \\
\text { kuesioner }\end{array}$ & $\begin{array}{l}\text { Tampil tabel } \\
\text { pebandingan } \\
\text { kuesioner }\end{array}$ & $\begin{array}{l}\text { Apabila ada } \\
\text { perbandingan data } \\
\text { yang tidak diisi akan } \\
\text { muncul warning }\end{array}$ & Sukses \\
\hline $\begin{array}{l}\text { Memilih } \\
\text { menu } \\
\text { "Sintesis" }\end{array}$ & $\begin{array}{l}\text { Menu } \\
\text { "Sintesis" }\end{array}$ & $\begin{array}{l}\text { Akan muncul } \\
\text { tabel sintesis } \\
\text { yang dapat } \\
\text { diurutkan }\end{array}$ & $\begin{array}{l}\text { Ada hasil berupa tabel } \\
\text { alternatif sanksi yang } \\
\text { telah disimpan }\end{array}$ & Sukses \\
\hline $\begin{array}{l}\text { Pilih tombol } \\
\text { "logout" }\end{array}$ & $\begin{array}{l}\text { Tombol } \\
\text { "logout" }\end{array}$ & $\begin{array}{l}\text { Menuju ke } \\
\text { halaman } \\
\text { awal/home }\end{array}$ & $\begin{array}{l}\text { Jika tombol "logout" } \\
\text { dipilih maka akan } \\
\text { keluar dari sistem }\end{array}$ & Sukses \\
\hline
\end{tabular}

Dari kelompok (cluster), kriteria dan subkriteria, serta alternatif yang telah diidentifikasi kemudian dilakukan penentuan pemodelan hubungan antar kriteria. Ada dua kontrol yang perlu diperhatikan didalam memodelkan sistem yang hendak diketahui bobotnya. Kontrol pertama adalah kontrol hierarki yang menunjukkan keterkaitan kriteria dan subkriterianya. Kontrol lainnya adalah kontrol keterkaitan yang menunjukkan adanya saling keterkaitan antar kriteria [8]. 
Hubungan antar kriteria yang telah dimodelkan dibuatkan perbandingan berpasangan untuk menghitung dampaknya terhadap alternatif-alternatif menggunakan skala rasio pengukuran 1-9. Perbandingan berpasangan ini dilakukan melalui kuesioner kepada tiga orang praktisi sekolah, yaitu wakil kepala sekolah bidang kesiswaan yang berperan sebagai pemangku keputusan, koordinator bimbingan konseling yang melakukan evaluasi terhadap kondisi siswa, dan pembina OSIS yang menerapkan langsung peraturan serta kedisiplinan siswa. Ketiganya berperan langsung dalam manajemen kesiswaan, menurut Mulyasa [9] bahwa hal yang paling penting dalam implementasi manajemen berbasis sekolah adalah manajemen terhadap komponen-komponen sekolah itu sendiri, salah satunya adalah manajemen kesiswaan.

Uji sensitivitas dilakukan untuk mengetahui apakah perubahan kebijakan sekolah mempengaruhi hasil keputusan penanganan/tindakan pelanggaran siswa. Perubahan kebijakan yang mungkin terjadi di SMK Infokom Bogor adalah perubahan kebijakan sanksi. Untuk itu, uji sensitivitas pada penelitian ini dilakukan dengan mencoba merubah penilaian terhadap salah satu alternatif yaitu peringatan lisan dan istigfar (A1). Perubahan penilaian menyebabkan nilai bobot untuk setiap Alternatif juga ikut berubah. Perubahan nilai bobot alternatif untuk uji sensitivitas dapat dilihat pada Tabel 5 .

Setelah dilakukan uji sensitivitas, maka diketahui bahwa perubahan kebijakan sekolah terhadap alternatif tindakan/ penanganan yaitu peringatan lisan dan istigfar (A1) mempengaruhi hasil akhir keputusan penanganan pelanggaran siswa. Hasil dari uji sensitivitas menunjukkan bahwa nilai bobot alternatif yang lain mengalami penurunan. Grafik penurunan bobot alternatif tindakan/penanganan siswa dapat dilihat seperti pada Gambar 3. Hasil pengujian black box dari sistem ditampilkan pada Tabel 6.

\section{Kesimpulan}

Sistem penunjang keputusan strategi atas pelanggaran siswa SMK Infokom Bogor ini dibuat dengan menggunakan metode Analytical Network Process dengan bahasa pemrograman PHP, database MySQL serta Super Decision sebagai aplikasi pengolah data pakar. Hasil dari penelitian ini berupa pemeringkatan alternatif penanganan siswa sebagai strategi tindakan yang dapat diterapkan oleh pihak sekolah dalam mengupayakan kedisiplinan siswa. Dari hasil penelitian didapatkan pemeringkatan alternatif yang menghasilkan bahwa penanganan pelanggaran siswa berupa peringatan tertulis dan hukuman edukatif merupakan hasil yang mendapatkan nilai tertinggi sesuai dari ketiga pendapat pakar dalam penelitian ini yaitu Wakil Kepala Sekolah Bidang Kesiswaan, Koordinator Bimbingan Konseling dan Pembina OSIS. Hal ini menunjukkan bahwa penanganan yang paling efektif untuk diterapkan pada SMK Infokom Bogor adalah peringatan tertulis dan hukuman edukatif.

Selain pemeringkatan alternatif tindakan siswa, didapatkan pula pemeringkatan pelanggaran yang menghasilkan bahwa pelanggaran berupa datang terlambat lebih dari tiga puluh menit tanpa keterangan merupakan pelanggaran yang paling utama untuk dapat dilakukan tindakan/penanganan saat ini. Hasil pemeringkatan ini dapat dijadikan sebagai bahan evaluasi pihak sekolah dalam mengupayakan kedisiplinan.

\section{References}

[1] Triliyana, D. Sistem Pendukung Keputusan penentuan Sanksi Pelanggaran Siswa di SMK AI Hikmah Mayong Jepara. Skripsi. Universitas Muria Kudus. 2015

[2] Handayani. Sistem Pendukung keputusan Untuk Menentukan Tingkat Kedisiplinan dan Sanksi Pelanggaran Siswa di SMAN 1 Jatinom. Skripsi. Universitas Muhammadiyah Surakarta. 2015

[3] Krisnuari, D. Sistem Pendukung Keputusan Sanksi Pelanggaran Tata Tertib Sekolah di SMK Negeri Tugumulyo Menggunakan Metode Topsis. Skripsi. Bina Nusantara Jaya. 2015

[4] Turban, Efraim dan Jaye Aronson. Decision Support Systems and Intelligent Systems. Fifth Edition. Prentice-Hall, Inc. 1998.

[5] Kendall \& Kendal. Systems Analysis and design. 4th edition, Prentice Hall, Inc. 1999

[6] Suradinata, Manajemen Sumber Daya Manusia, Ramadan Bandung. 1996

[7] Saaty, T.L. and Vargas, L.G. Models, Methods, Concepts and Applications of the Analytic Hierarchy Process, Boston: Kluwer Academic Publishers. 2000

[8] Saaty, T. L., Decision Making with Dependence and Feedback-The Analytic Network Process, RWS Publications, Pittsburgh. 1996, 
[9] Mulyasa, E. Kurikulum Berbasis Kompetensi. Konsep, Karakteristik, dan Implementasi. Bandung: Rosdakarya. 2002 